\title{
Didactic materials: Mannequin for canine abdominal and vaginal palpation
}

\author{
Material didático: Manequim para palpação abdominal e vaginal em cães \\ Materiales didácticos: Maniquí para palpación vaginal y abdominal canina
}

Received: 02/10/2021 | Reviewed: 02/14/2021 | Accept: 02/17/2021 | Published: 02/25/2021

\author{
Andreia Nobre Anciuti \\ ORCID: https://orcid.org/0000-0001-9930-6234 \\ Universidade Federal de Pelotas, Brazil \\ E-mail: vet.andreia@gmail.com \\ Antonio Sergio Varela Junior \\ ORCID: https://orcid.org/0000-0003-4901-5118 \\ Universidade Federal de Pelotas, Brazil \\ E-mail: varelajras@gmail.com \\ Talita Lobo Ochôa \\ ORCID: https://orcid.org/0000-0003-3103-1494 \\ Universidade Federal de Pelotas, Brazil \\ E-mail: thalitalobochoa@hotmail.com \\ Betina Keidann \\ ORCID: https://orcid.org/0000-0002-1577-256X \\ Universidade Federal de Pelotas, Brazil \\ E-mail: betinamkeidann@gmail.com \\ Luísa Grecco Corrêa \\ ORCID: https://orcid.org/0000-0003-1355-2907 \\ Universidade Federal de Pelotas, Brazil \\ E-mail: luisagcorrea@gmail.com \\ Joseane de Lima Andrades \\ ORCID: https://orcid.org/0000-0002-4345-9781 \\ Universidade Federal de Pelotas, Brazil \\ E-mail: joseanadelima@hotmail.com \\ Carine Dahl Corcini \\ ORCID: https://orcid.org/0000-0001-5683-7801 \\ Universidade Federal de Pelotas, Brazil \\ E-mail: corcinicd@gmail.com
}

\begin{abstract}
Compared to the veterinary education system decades ago, ethical and welfare questions are of major relevance in the current scenario. Therefore, certain learning practices involving in vivo animal studies are no longer performed. To overcome this limitation, the use of mannequins has emerged as an interactive and immersive method of learning that simulates a real situation. The aim of this work is development mannequins for improve physiology of the reproductive apparatus of a bitch. Here, we used a plastic canine prototype to simulate the abdominal and vaginal palpation technique. An abdominal incision was made, filled with synthetic fiber, and a fictional uterus was placed. In the same mannequin, an orifice was created that correspond to the vagina. This model greatly helped in training students in performing palpation techniques, conducting the static evaluation, and assessing maternal-fetal ratio. Moreover, the physiology of the reproductive canine prototype made possible the demonstration of abdominal and vaginal palpation. This practice of vaginal palpation was found to be of great value since several students could easily take the examination and identify different stages of canine gestation, which could hardly be achieved using animals. Mannequins have received good student acceptance owing to their safety and ease to use, and resulted in a better understanding of the procedure to perform future in vivo animal studies.
\end{abstract}

Keywords: Canine prototype teaching approaches; Animal simulator; Pregnancy palpation; Palpation examination; Hands-on learning.

\section{Resumo}

Em comparação com o sistema de educação veterinária de décadas atrás, as questões éticas e de bem-estar são de grande relevância no cenário atual. Portanto, certas práticas de aprendizagem envolvendo estudos em animais in vivo não são mais realizadas. Para superar essa limitação, o uso de manequins surgiu como um método interativo e imersivo de aprendizagem que simula uma situação real. O objetivo deste trabalho é desenvolver manequins para melhorar o estudo em fisiologia do aparelho reprodutor de uma cadela. Utilizamos um protótipo canino de plástico para simular a técnica de palpação abdominal e vaginal. Foi feita uma incisão abdominal preenchida com fibra 
sintética e colocado um útero fictício. No mesmo manequim, foi criado um orifício que corresponde à vagina. Esse modelo ajudou muito no treinamento dos alunos na execução das técnicas de palpação, na avaliação estática e na avaliação da proporção materno-fetal. Além disso, a fisiologia do protótipo reprodutivo canino possibilitou a demonstração da palpação abdominal e vaginal. Essa prática de palpação vaginal mostrou-se de grande valia, uma vez que vários alunos puderam facilmente realizar o exame e identificar diferentes estágios da gestação canina, o que dificilmente seria alcançado com animais. Os manequins foram bem aceitos pelos alunos devido à sua segurança $\mathrm{e}$ facilidade de uso, e resultaram em uma melhor compreensão do procedimento para realizar futuros estudos em animais in vivo.

Palavras-chave: Abordagens de ensino de protótipos caninos; Simulador de animais; Palpação da gravidez; Exame de palpação; Aprendizagem prática.

\section{Resumen}

En comparación con el sistema de educación veterinaria de décadas atrás, las encuestas éticas y bienales son de gran relevancia en el escenario actual. Por lo tanto, no se realizarán experiencias prácticas de aprendizaje que involucren estudios en animales in vivo. Para superar esta limitación, surgió el uso de maniquíes como un método de aprendizaje interactivo e inmersivo que simula una situación real. El propósito de este trabajo es desarrollar maniquíes para mejorar el estudio en fisiología de un sistema reproductivo. Utilizamos un prototipo canino de plástico para simular la técnica de palpación abdominal y vaginal. Si se hace una incisión abdominal hueca de fibra sintética y se coloca un útero ficticio. En el maniquí se creó un orificio que corresponde a la vagina. Este modelo ayudó mucho en la formación de los estudiantes en la aplicación de técnicas de palpación, en la evaluación estática y en la evaluación de la proporción materno-fetal. Además, la fisiología del prototipo reproductivo canino permite la demostración de la palpación abdominal y vaginal. Esta práctica de palpación vaginal resultó ser de gran valor, ya que muchas alumnas pudieron fácilmente realizar el examen e identificar diferentes etapas del embargo canino, lo cual sería difícil de lograr con los animales. Los maniquíes fueron bien aceptados por los estudiantes debido a su seguridad y facilidad de uso, y resultaron en una mejor comprensión del procedimiento para realizar futuros estudios en animales in vivo.

Palabras clave: Enfoques de enseñanza de prototipos caninos; Simulador de animales; Palpación del embarazo; Examen de palpación; Aprendizaje práctico.

\section{Introduction}

The development of audiovisual and tactile resources has immensely contributed to technological evolution. These novel education modalities also provide students with the necessary abilities, knowledge, and comprehension required in the veterinary profession. A remarkable advancement is encouraging the adoption of alternative resources to minimize the use of animals in vivo in practical classes (Martinsen, 2005; Riveira, 2006; Furlan and Fischer, 2020). This has become an important principle of veterinary practice to protect animals. However, during veterinary medicine study, undergraduates are faced with difficult situations, involving excessive manipulation, performing euthanasia of animals to study anatomy and physiology and various clinical and surgical aspects. These challenges often make the study of this specialty not very attractive and involve considerable ethical and moral aspects (Fletcher, 2012, Schoenfeld-Tacher et al., 2015).

The predilection for didactic materials in experimentation and other teaching activities is attributed to increased ethical consideration of animal welfare, students' ethical development, and the availability of new alternative methods that satisfactorily imitate structures and circumstances involved in clinical and surgical professional routines. It is especially important for those students who feel insecure while performing maneuvers for the first time in living models. In this way, the use of model animals has become an optional and less determinant situation for providing quality education in certain subjects of the veterinary medicine course (Martinsen, 2005).

Since the 1960s, the premise of "3 R's Principles on Animal Experimentation (Replacement, Reduction, and Refinement)" determined by Russel and Burch, laid the foundation for mimicking animal application, using mannequins, prototypes, and other devices. In addition, recognizing the importance of practical teaching activities that favor adherence of knowledge to the perspective of meaningful learning, the National Council for Control of Animal Experimentation (CONCEA) in Brazil, within its competencies, encourages the introduction of alternative methods in place of animals in both research and 
teaching (Marques, 2005; Silva, 2020; Silva et al., 2021). Therefore, ideal replacement methods for teaching practices involve model for training and after that, skills can be improved with animals that need intervention (Martinsen, 2005).

Prototypes and mannequins include synthetic objects designed to replicate or simulate organs (limbs or whole animals) and physiological functions to teach clinical skills, including those required in critical care. In this context, the present work aims to describe a canine mannequin capable of mimicking the abdominal and vaginal palpation of a pregnant female.

\section{Methodology}

To simulate the abdominal and vaginal palpation technique, a plastic canine prototype was employed in which an abdominal opening was created (Figure 1). Subsequently, the internal space was filled with synthetic fiber (Figure 2) to the point where the fictitious uterus by 28 days (Figure 3) reached the surface to facilitate the sensitivity of the "fetuses" (Concannon et., 2001; Johnston et al., 2001). Simulators of uterus and fetuses were created for various stages of fetal development. Next, the region was topped with a Non Woven Fabric square. An orifice was also created in the region corresponding to the vagina. To simulate the vestibular mucosa, a "finger of procedure glove" was used by inverting and fixing it to the interior of the mannequin, providing training to students in palpation techniques, static assessment, and knowledge of maternal-fetus ratio.

Figure 1 - Plastic canine prototype was employed in which an abdominal opening.

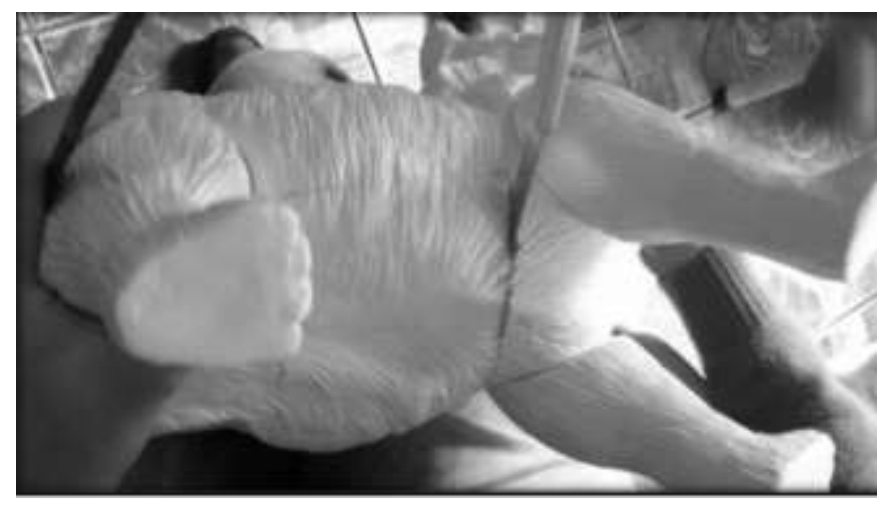

Fonte: Authors.

Figure 2 - Abdominal space filled with synthetic fiber.

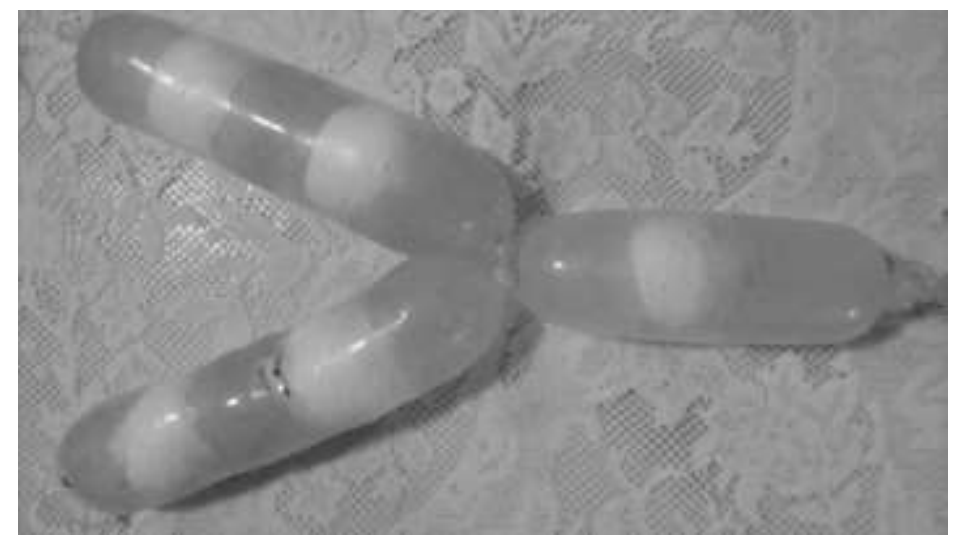

Fonte: Authors. 
Figure 3 - Fictitious uterus filled by mucilage interspersed with ballon balls filled with modeling mass.

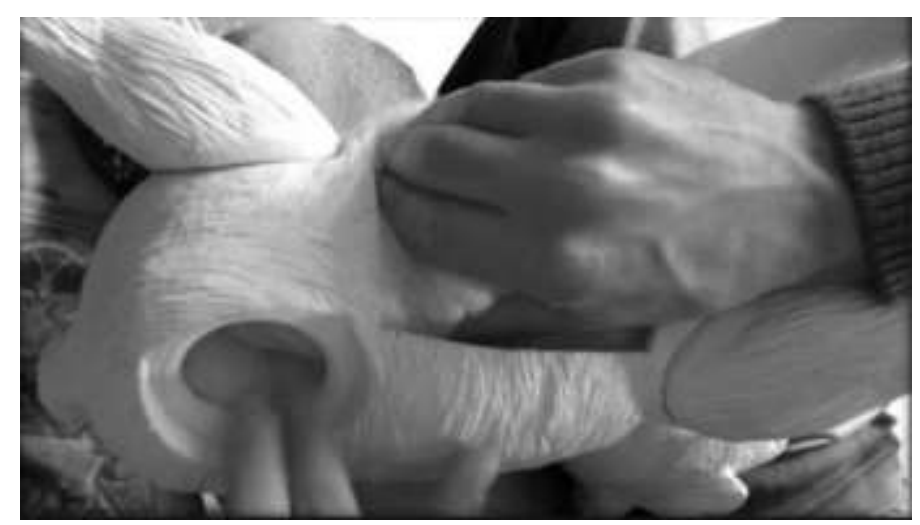

Fonte: Authors.

From the sample of 300, only $45 \%$ answered the questionnaire applied after the curricular component closure. Between the use of the manikin and the closure of the curricular component, it took an average of 30 days (Ludke e Andre, 2013). Pesquisas em educação: uma abordagem qualitativa. São Paulo: E.P.U. The academics were asked to perform an anonymous examination in the teacher evaluation system, where they should report the activity developed with the manikin and the degree of comfort in practicing the technique.

\section{Results and Discussion}

The present study describes the use of mannequins to train students in the field of as part of their practical veterinary course. The undergraduates expressed both a feeling of curiosity and security toward this approach. This prototype allowed "patient care" to be a significant attribute of the existing medical clinic routine. Thus, training and improvement of abdominal and vaginal palpation techniques, as well as general and specific examination of the female reproductive tract, were presented in theoretical classes.

The main motivation for developing this mannequin was to provide students with an opportunity to practice abdominal and vaginal palpation in a pregnant canine female in different stages of embryonic development and evaluate the fetal statics. This increased confidence among students, and consequently, prepared them to perform a gestation diagnosis as part of dog clinical veterinary routine. These procedures provided technical advancements in gestation diagnosis, identification of gestational stage, and prenatal follow-up. The palpation pregnancy diagnosis is always indicated because it is an early, safe, and cheap method; however, it requires extreme professional precision.

The use of alternative didactic materials has increased the interest and curiosity of veterinary students, who reported a greater comprehension of procedures and safety in performing future in vivo animal studies. Students require practical experience to deal with living tissues and animals. To achieve this, the development of methodologies that bring the undergraduates closer to reality such as consultations, simulations, and the introduction of tactile resources, such as a mannequin, attract the attention of students as compared to videos and other audiovisual resources. It is an important training tool that enables students to feel more secure (Martinsen, 2005; Almeida \& Conceição, 2020; Soares \& Barros, 2020; Silva et al., 2021)

Plastic models are used to demonstrate internal structures, such as morphology and orthopedics, to exemplify fracture types. Mannequins are increasingly used as a clinical training tool to perform palpation, blood collection, intubation, thoracentesis, and cardiopulmonary resuscitation. Simulators, in turn, are developed to facilitate the learning of surgical 
techniques, critical care, and clinical practices (Martinsen, 2005). These are alternatives to provide greater skill and safety to undergraduates.

Mannequins have found more frequent use in human medicine. The first prototype marketed in veterinary medicine was the "Jerry Dog for Critical Care," a perfect model for emergency care training. It integrates a digital simulator of breathing and heart sounds, as well as opportunities to practice intubation, cardio-respiratory resuscitation, intravenous accession, and other skills (Fletcher, 2012). The use of static mannequins for teaching provides a safe learning environment, reduces animal suffering, decreases stress and/or fears of students, prepares students for future patient procedures, and reproduces structures and situation in a real way. The absence of emotions, such as anxiety, stress, and insecurity may be beneficial to students; emotional states induced by harmful practices can directly affect learning and memory (Marques, 2005)

\section{Final Considerations}

In addition to being economically viable, elaboration of mannequins using simple and easy to execute techniques makes the practical application of these models more palpable, dynamic, interesting, and readily available to students. Moreover, it does not require a pregnant animal to perform the techniques. These resources are expected to accurately train veterinary students to achieve greater self-confidence while performing future in vivo procedures.

\section{Acknowledgments}

This work was conducted during a scholarship financed by CAPES - Brazilian Federal Agency for Support and Evaluation of Graduate Education within the Ministry of Education of Brazil. Research grants from Antonio Sergio Varela Junior (310327/2018-0) and Carine Dahl Corcini (310203/2018-0).

\section{References}

Almeida, N. P. \& Santos, K. G dos. (2020). Ensino do Laboratório de Engenharia Química baseado em projeto: adsorção de gasolina empregando casca de banana. Research, Society and Development, 9 (3), 1-25.

Concannon, P. W., Tsutsui, T., \& Shille, V. (2001). Embryo development, hormonal requirements and maternal responses during canine pregnancy. J Reprod Fertil, Suppl n.57, 169-179.

Fletcher, D. J., Militello, R., Schoeffler, G. L., \& Rogers, C. L. (2012). Development and evaluation of a high-fidelity canine patient simulator for veterinary clinical training. Journal of Veterinary Medical Education, 39 (1), 7-12.

Furlan, A. L. D. \& Fisher, M. L. (2020) Métodos Alternativos Ao Uso De Animais Como Recurso Didático: Um Novo Paragima Bioético Para O Ensino Da Zoologia. Educação em Revista, 36.

Johnston, S. D., Root Kustritz, M. V., \& Olson, P. N. S (Ed.). (2001). Canine and feline theriogenology. Philadelphia: Saunders,

Ludke, M. \& Andre, M. E. D. A. (2013). Pesquisas em educação: uma abordagem qualitativa: E.P.U.

Marques, R. G., Miranda, M. L., Caetano, C. E. R., \& Biondo-Simões, M. L. P. (2005). Rumo à regulamentação da utilização de animais no ensino e na pesquisa científica no Brasil. Acta Cirúrgica Brasileira, 20, (3).

Martinsen, S., \& Jukes N. (2005). Toward a humane veterinary education. Journal of Veterinary Medical Education, 32(4), 454-60.

Riveira, E. A. B. (2006). Legislação e Comitês De Ética Na Experimentação Animal. In: Rivera, E. A. B., Amaral, M. H., Nascimento, V. P. Ética e bioética aplicada à medicina veterinária: Goiânia, 187-212.

Schoenfeld-Tacher, R. M., Kogan, L. R., Meyer-Parsons, B., Royal, K. D., \& Shaw, J. R. (2015). Educational Research Report: Changes in Students' Levels of Empathy during the Didactic Portion of a Veterinary Program. Journal of Veterinary Medical Education, 42(3), 194-205.

Silva, J. B. (2020). A Teoria da Aprendizagem Significativa de David Ausubel: uma análise das condições necessárias. Research, Society and Development, $9(3), 1-13$.

Silva, L. K. A., Silva, M. D. G., Sales, P. F, Góis, P., \& Ferreira, W. J. (2021). Estratégias complementares ao ensino de Química. Research, Society and Development, 10(1), e19110111660. 
Research, Society and Development, v. 10, n. 2, e48810212847, 2021

(CC BY 4.0) | ISSN 2525-3409 | DOI: http://dx.doi.org/10.33448/rsd-v10i2.12847

Soares,C. S., \& Barros, M. A. (2020). Modelos didáticos para avaliação estrutural. Research, Society and Development, 9 (10), e039108323. 